\title{
Perencanaan Dermaga LNG Kabupaten Maros Sulawesi Selatan
}

\author{
Fahmi Shofi Aulia, Fuddoly dan Dyah Iriani Widyastuti \\ Departemen Teknik Sipil, Institut Teknologi Sepuluh Nopember (ITS) \\ e-mail:dyah1961@gmail.com
}

\begin{abstract}
Abstrak-Indonesia merupakan Negara yang memiliki cadangan gas bumi yang besar. Sampai saat ini gas alam yang berasal di Indonesia diolah menjadi produk LNG (liquefied natural gas). LNG merupakan gas alam yang telah diolah kedalam bentuk cair yang telah dikondensasikan sampai suhu $-161^{\circ} \mathrm{C}$ agar volume yang dihasilkan berkurang sampai 1/600 dari fasa gasnya sehingga menjadi Natural gas. Pembangunan dermaga LNG di Kabupaten Maros untuk kapal 10.000 DWT merupakan solusi yang dapat memecahkan permasalahan pendistribusian untuk daerah daerah yang membutuhkan suplai gas, salah satu indikatornya adalah Maros merupakan daerah yang strategis, hal ini didukung dengan posisi Maros yang berada di tengah diantara daerah tujuan serta terletak pada Alur Laut Kepulauan Indonesia II sehingga kegiatan pendistribusian LNG dengan mudah dilakukan baik itu ke dalam maupun luar negeri. Untuk menunjang kegiatan operasional tersebut maka dibangunlah dermaga LNG dengan tahapan pembangunan dimulai dengan mengumpulkan dan menganalisa data yang dibutuhkan dimana data tersebut digunakan untuk mengevaluasi layout perairan dan daratan. Kemudian direncanakan detail struktur dermaga, metode pelaksanaan, dan rencana anggaran biaya. Hasil dari perencanaan struktur dermaga LNG berupa unloading platform ( $22 \mathrm{~m} \times 19 \mathrm{~m}$ ), breasting dolphin $(5,4 \mathrm{~m} \times 5,2 \mathrm{~m})$, mooring dolphin ( $4 \mathrm{~m} \times 4 \mathrm{~m}$ ), dan catwalk ( $7 \mathrm{~m}, 16 \mathrm{~m}, 28 \mathrm{~m}$ ). Metode pelaksanaan yang digunakan menggunakan metode in-situ (in place). Dan dengan estimasi biaya Rp. 49.843.444.000 (Empat puluh sembilan miliar delapan ratus empat puluh tiga juta empat ratus empat puluh empat ribu rupiah).
\end{abstract}

Kata Kunci-Dermaga, Kapal 10.000 DWT, LNG, Struktur Dermaga.

\section{PENDAHULUAN}

$\mathrm{I}$ NDONESIA merupakan salah satu negara yang memiliki cadangan gas bumi yang besar. Gas alam yang berada di Indonesia menunjukkkan suatu hal yang positif dan berpotensi tinggi untuk dimanfaatkan. Sampai saat ini gas alam yang berasal di Indonesia diolah menjadi produk Liquefied Natural Gas (LNG) dan juga Liquefied Petroleum Gas (LPG). LNG merupakan gas alam yang telah diolah kedalam bentuk cair yang telah dikondensasikan sampai suhu $-161^{\circ} \mathrm{C}$ agar volume yang dihasilkan berkurang sampai 1/600 dari fasa gasnya sehingga menjadi Natural gas. Pemanfaatan LNG sebagai energi alternatif kian terasa. Contohnya penggantian bahan baku batu bara dengan memakai LNG pada salah satu industri pembangkit listrik. Hal ini mengakibatkan penggunaan gas alam di dunia sebagai energi alternatif terus meningkat dari tahun ke tahun.

Maros merupakan salah satu daerah di Sulawesi Selatan dimana pelabuhan khusus LNG akan dibangun. Lokasi tersebut dipilih dikarenakan daerah tersebut merupakan solusi yang dapat memecahkan permasalahan pendistribusian untuk daerah daerah yang membutuhkan suplai gas tersebut, salah satu indikatornya adalah Maros merupakan daerah yang strategis, hal ini didukung dengan posisi Maros yang berada di tengah diantara daerah tujuan serta terletak pada Alur Laut

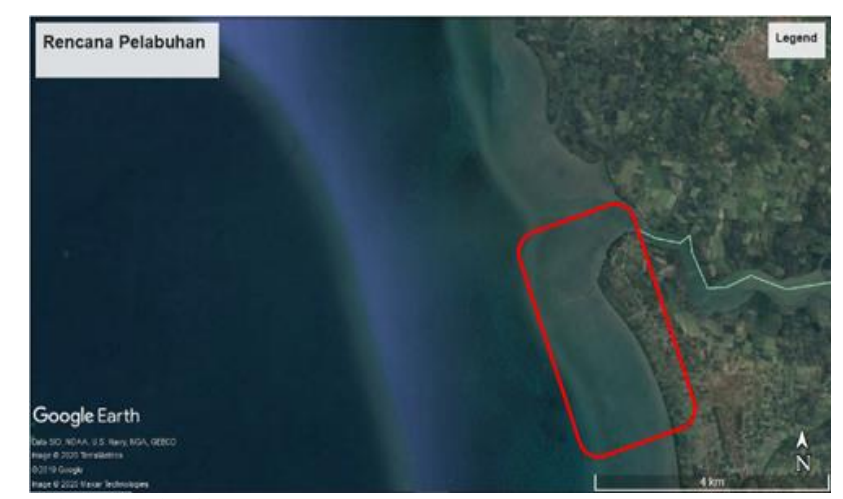

Gambar 1. Lokasi Perencanaan Dermaga LNG.

Kepulauan Indonesia II sehingga kegiatan pendistribusian LNG dengan mudah dilakukan baik itu ke dalam maupun luar negeri.

Pada penelitian ini akan mengkhususkan pada perencanaan dermaga yang berlokasi di Maros, dimana dermaga ini akan digunakan untuk proses unloading LNG. Sehingga dibutuhkan suatu desain struktur dermaga yang memenuhi standar operasi dan safety yang berlaku. Perlu diperhatikan juga untuk pembangunan Pelabuhan LNG ini membutuhkan suatu perlakuan khusus dikarenakan sifatnya yang mudah terbakar dan mampu membuat baja getas [1].

Lokasi perencanaan dermaga LNG di Maros Sulawesi Selatan untuk kapal LNG kapasitas 10.000 DWT secara terperinci ditunjukkan oleh Gambar 1. .Lokasi pengembangan berada pada koordinat Garis Lintang $5^{\circ} 11^{\prime} 7.69^{\prime \prime S ~ d a n ~ G a r i s ~}$ Bujur 119²8'18.64"E.

\section{URAIAN PENELITIAN}

\section{A. Tahap Persiapan}

Tahap persiapan merupakan serangkaian kegiatan sebelum dimulainya kegiatan pengumpulan dan pengolahan data. Tahap persiapan ini dilakukan bertujuan untuk mengefektifkan waktu dan mempermudah pengerjaan. Adapun tahap persiapan meliputi perumusan dan mengidentifikasi masalah, penentuan kebutuhan data dan studi lapangan dengan menggunakan Google Earth maupun NCDC NOAA untuk mengetahui lokasi perencanaan pengemembangan dermaga LNG di Maros Sulawesi Selatan.

\section{B. Studi Literatur}

Studi literatur bertujuan untuk mengetahui dasar teori dan rumus-rumus yang digunakan dalam perencanaan. Literatur yang digunakan didapatkan dari peraturan-peraturan, jurnal, buku dan internet.

\section{Pengumpulan Data}

Untuk melakukan analisa perhitungan dalam perencanaan dermaga, maka dibutuhkan data-data penunjang. Data yang diperlukan untuk melakukan analisa layout perairan dan 
Tabel 2.

Rekapitulasi Layout Perairan

\begin{tabular}{|c|c|c|c|c|c|c|c|}
\hline \multirow[t]{2}{*}{ No. } & \multicolumn{2}{|c|}{ Fasilitas Periaran } & Rencana Awal & \multicolumn{2}{|c|}{ Evaluasi } & \multicolumn{2}{|c|}{ Digunakan } \\
\hline & Areal & Radius & $-m$ & 230 & $\mathrm{~m}$ & 230 & $\mathrm{~m}$ \\
\hline \multirow[t]{2}{*}{1} & Penjangkara & Jumlah & - buah & 4 & buah & 4 & buah \\
\hline & $\mathrm{n}$ & Kedalaman & - $\quad$ mLWS & -14 & mLWS & -14 & mLWS \\
\hline \multirow{3}{*}{2} & & Stopping Distance & $-\quad \mathrm{m}$ & 2750 & $\mathrm{~m}$ & 2750 & $\mathrm{~m}$ \\
\hline & Alur Masuk & Kedalaman & - $\quad$ mLWS & -10 & mLWS & -10 & mLWS \\
\hline & & Jari-Jari Tikungan & $-m$ & - & $\mathrm{m}$ & - & $\mathrm{m}$ \\
\hline 3 & Kolam Putar & Kedalaman & - $\quad$ mLWS & -10 & mLWS & -10 & mLWS \\
\hline \multirow{3}{*}{4} & & Lebar & $-\quad m$ & 30 & $\mathrm{~m}$ & 30 & $\mathrm{~m}$ \\
\hline & Kolam & Panjang & $-\quad m$ & 180 & $\mathrm{~m}$ & 180 & $\mathrm{~m}$ \\
\hline & Dermga & Kedalaman & $-\quad m$ & -10 & $\mathrm{~m}$ & -10 & $\mathrm{~m}$ \\
\hline
\end{tabular}

Tabel 1

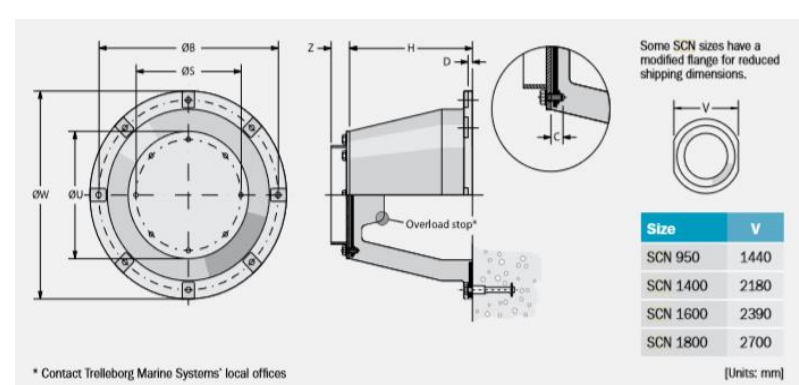

Gambar 2. Fender SCN 1800 F 0.7.

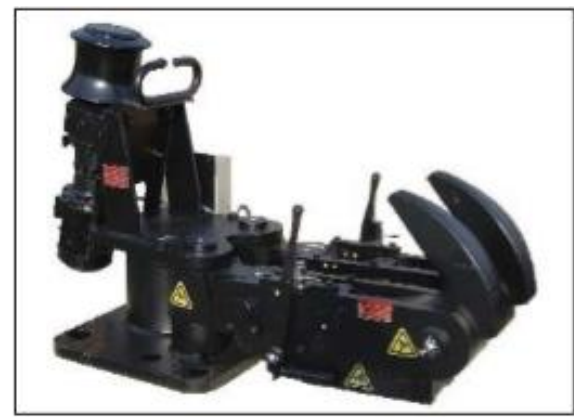

Gambar 3. Quick Release Hook (Double hook assembly).

daratan meliputi data peta batimetri dan data pasang surut perairan sekitar lokasi perancangan serta arus untuk pertimbangan alur masuk. Adapun data yang digunakan untuk merencanakan struktur dari dermaga meliputi data angin untuk peramalan gelombang, data arus untuk pembebanan struktur dan data tanah untuk perencanaan pondasi dermaga.

\section{Tahap Perencanaan}

Setelah semua data yang dibutuhkan telah terkumpul, maka selanjutnya dapat dilakukan perencanaan. Adapun perencanaan yang dilakukan meliputi kriteria desain, layout perairan dan daratan, perencanaan struktur, metode pelaksanaan dan perhitungan rencana anggaran biaya.

Tahapan kriteria desain meliputi jenis kapal yang digunakan, alat berat yang digunakan, penentuan kualitas material dan bahan, perencanaan fender dan perencanan bollard. Kapal yang digunakan dalam perencanaan dermaga pupuk NPK ini adalah kapal LNG dengan kapasitas 10.000 DWT, sedangkan alat berat yang digunakan adalah Marine Loading Arm, Fire Monitor Tower, Tower Gangway. Untuk kualitas bahan dan material digunakan kualitas beton K 350 dengan dan kualitas baja BjTS 40. Material tiang pancang menggunakan tiang pancang jenis SPP 812,8 mm dengan ketebalan $16 \mathrm{~mm}$ dari PT. Swarna Bajapacific. Tahapan selanjutnya adalah perencanaan fender dengan melakukan perhitungan energi dari tumbukan kapal yang telah dikalikan dengan safety factor dari kapal LNG menjadi energi abnormal
Rekapitulasi Layout Daratan

\begin{tabular}{|c|c|c|c|}
\hline No & & onen & Dimensi \\
\hline \multirow{3}{*}{1} & \multirow{3}{*}{$\begin{array}{l}\text { Unloading } \\
\text { Platform }\end{array}$} & Panjang & $19 \mathrm{~m}$ \\
\hline & & Lebar & $22 \mathrm{~m}$ \\
\hline & & Elevasi & $+6 \mathrm{~m}$ \\
\hline \multirow{5}{*}{2.} & \multirow{6}{*}{ Dolphin } & $\begin{array}{c}\text { Jarak MD - MD } \\
\text { (Inner) }\end{array}$ & $87 \mathrm{~m}$ \\
\hline & & $\begin{array}{c}\text { Jarak MD - MD } \\
\text { (Outter) }\end{array}$ & $167 \mathrm{~m}$ \\
\hline & & Panjang & $4 \mathrm{~m}$ \\
\hline & & Lebar & $4 \mathrm{~m}$ \\
\hline & & Tebal & $1 \mathrm{~m}$ \\
\hline \multirow{7}{*}{3.} & & Elevasi & $+3,80 \mathrm{~m}$ \\
\hline & \multirow{5}{*}{$\begin{array}{c}\text { Breasting } \\
\text { Dolphin }\end{array}$} & Jarak BD-BD & $45 \mathrm{~m}$ \\
\hline & & Panjang & $5,4 \mathrm{~m}$ \\
\hline & & Lebar & $5,2 \mathrm{~m}$ \\
\hline & & Tebal & $1,5 \mathrm{~m}$ \\
\hline & & Elevasi & $+3,80 \mathrm{~m}$ \\
\hline & Catwalk 1 & Panjang & $7 \mathrm{~m}$ \\
\hline \multirow{3}{*}{4.} & Catwalk 2 & Panjang & $16 \mathrm{~m}$ \\
\hline & Catwalk 3 & Panjang & $28 \mathrm{~m}$ \\
\hline & Catwalk 1,2,3 & Lebar & $1 \mathrm{~m}$ \\
\hline
\end{tabular}

kapal $\left(\mathrm{E}_{\mathrm{AB}}\right)$, setelah didapatkan energi abnormal kapal, dicari dalam brosur energi fender yang lebih besar dari energi abnormal kapal [2]. Perencanaan bollard hanya memperhatikan nilai displacement tonnage dari kapal LNG lalu dicari ditabel spesifikasi bollard.

Tahapan pertama evaluasi layout perairan dan daratan adalah menetukan lokasi dari dermaga yang akan direncanakan, dapat dilihat dari data peta batimetri. Setelah itu direncanakan layout perairan meliputi areal pengangkuran, alur masuk, kolam putar, dan kolam dermaga, sedangkan perencanaan layout daratan meliputi elevasi dermaga, dimensi unloading platfotm, mooring dolphin, breasting dolphin, dan catwalk.

Selanjutnya dilakukan perencanaan struktur dermaga LNG. Langkah pertama dalam perencanaan stuktur dermaga adalah menentukan dimensi dari pelat, balok, dan poer. Setelah itu dilakukan pemodelan struktur dengan software SAP2000 yang nantinya output dari hasil pemodelan digunakan untuk perhitungan tulangan balok, pelat, dan poer. Berkaitan dengan pembebanan yang terjadi khususnya beban gempa untuk mencari nilai kelas situs pada daerah tersebut didapatkan kelas situs SE (tanah lunak) dikarenakan nilai SPT yang terjadi di bawah 15 [3].

Perencanaan metode pelaksanaan meliputi tahapan-tahapan pekerjaan untuk membangun dermaga LNG, alat berat yang 
Tabel 4.

Rekapitulasi Momen Maksimum Pelat

\begin{tabular}{|c|c|c|c|c|c|c|c|c|}
\hline \multirow[t]{2}{*}{ Elemen Struktur } & \multirow[t]{2}{*}{ Lx } & \multirow[t]{2}{*}{ Ly } & \multirow{2}{*}{$\frac{L y}{L x}$} & \multirow{2}{*}{\multicolumn{2}{|c|}{ Koefisien X }} & \multicolumn{2}{|c|}{ Momen (kg.m) } & \multirow[b]{2}{*}{ Total } \\
\hline & & & & & & Mati & Hidup & \\
\hline \multirow{16}{*}{$\begin{array}{l}\text { Pelat Unloading } \\
\text { Platform }\end{array}$} & 1,6 & 1,7 & 1,1 & Mlx & 55 & 102,08 & 429,44 & 531,52 \\
\hline & 1,6 & 1,7 & 1,1 & Mly & 50 & 92,8 & 390,4 & 483,2 \\
\hline & 1,6 & 4,4 & 2,8 & Mtx & 54 & $-100,224$ & $-421,63$ & $-521,856$ \\
\hline & 1,6 & 4,4 & 2,8 & Mty & 56 & $-103,936$ & $-437,24$ & $-541,184$ \\
\hline & 1,7 & 5,3 & 3,1 & Mtx & 54 & $-113,144$ & $-475,98$ & $-589,126$ \\
\hline & 1,7 & 5,3 & 3,1 & Mty & 56 & $-117,334$ & $-493,61$ & $-610,946$ \\
\hline & 4,4 & 5,3 & 1,2 & Mlx & 46 & 645,656 & 2716,2 & 4363,864 \\
\hline & 4,4 & 5,3 & 1,2 & Mly & 38 & 533,368 & 2243,82 & 3567,192 \\
\hline & 1,7 & 5,4 & 3,2 & Mtx & 54 & $-113,144$ & $-475,98$ & $-589,127$ \\
\hline & 1,7 & 5,4 & 3,2 & Mty & 56 & $-117,334$ & $-493,61$ & $-610,946$ \\
\hline & 4,4 & 5,4 & 1,2 & Mlx & 46 & 681,28 & 2716,21 & 3397,49 \\
\hline & 4,4 & 5,4 & 1,2 & Mly & 38 & 562,8 & 2243,82 & 2806,62 \\
\hline & 1,7 & 1,7 & 1 & Mlx & 48 & 100,572 & 423,1 & 523,67 \\
\hline & 1,7 & 1,7 & 1 & Mly & 48 & 100,572 & 423,1 & 523,67 \\
\hline & 1,7 & 4,4 & 2,6 & Mlx & 46 & 101,7 & 405,467 & 507,16 \\
\hline & 1,7 & 4,4 & 2,6 & Mly & 38 & 84,01 & 334,95 & 418,96 \\
\hline
\end{tabular}

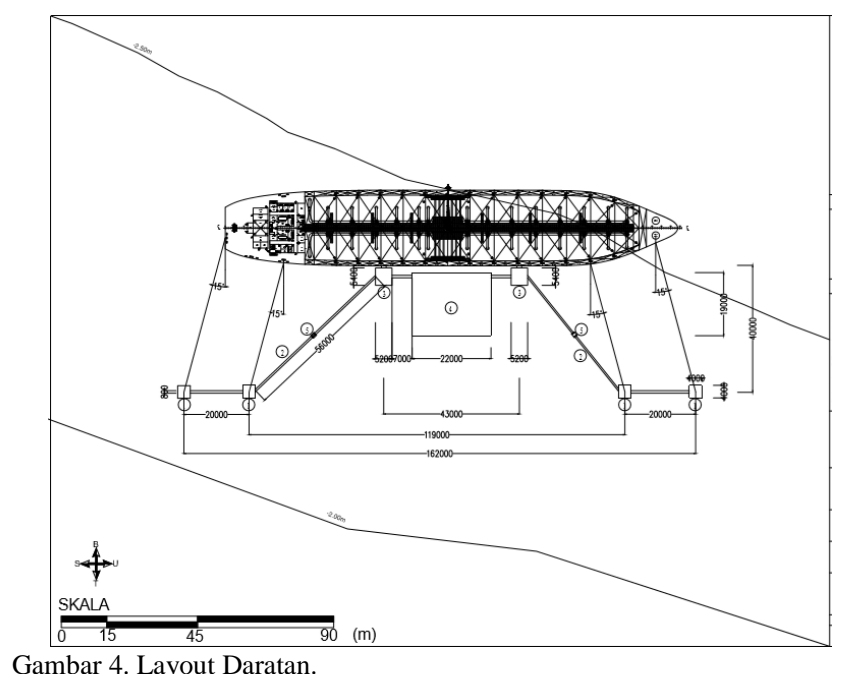

digunakan, dan pengetesan material saat pelaksanaan yang berlanjut pada perhitungan rencana anggaran biaya pembangunan dermaga LNG.

\section{HASIL DAN PEMBAHASAN}

\section{A. Perencanaan Fender dan Bollard}

Dengan $\mathrm{E}_{\mathrm{AB}}=152 \mathrm{tm}$, maka direncanakan untuk menggunakan sistem fender tunggal dari SCN 1800 F 0.7 dengan data-data sebagai berikut:
Energi
$=153,4$ ton.m
(> 152 ton.m)
Reaksi$$
=176,5 \text { ton }
$$
Berat fender $=6618 \mathrm{~kg}$

Detail dari fender dapat dilihat pada Gambar 2.

Dari spesifikasi kapal didapat gaya tarik maksimal pada bollard adalah 31,46 ton sehingga dipilih tipe Quick Release Hook (Double hook assembly) dengan spesifikasi sebagai berikut:

Kapasitas tarik bollard $=40$ ton

Berat $\quad=491 \mathrm{~kg}$

Detail dari bollard dapat dilihat pada Gambar 3.

\section{B. Evaluasi Layout Perairan dan daratan}

Evaluasi layout perairan dermaga LNG mengacu pada peraturan peraturan yang digunakan seperti OCDI, dan PIANC. Perencanaan ini harus memperhatikan semua aspek
Tabel 3.

Rekapitulasi Kebutuhan Tulangan Pelat

\begin{tabular}{cccccc}
\hline \hline $\begin{array}{c}\text { Elemen } \\
\text { Struktur }\end{array}$ & Arah & $\begin{array}{c}\text { M } \\
\text { (kg.m })\end{array}$ & $\begin{array}{c}\text { As perlu } \\
\left(\mathrm{mm}^{2}\right)\end{array}$ & $\begin{array}{c}\text { As pasang } \\
\left(\mathrm{mm}^{2}\right)\end{array}$ & Pasang \\
\hline \multirow{6}{*}{ Mlx } & 531,52 & 143,91 & 402,29 & D16-500 \\
& Mly & 483,2 & 142,99 & 402,29 & D16-500 \\
& Mtx & $-521,856$ & 139,43 & 402,29 & D16-500 \\
& Mty & $-541,184$ & - & 402,29 & D16-500 \\
Unloading & Mtx & $-589,126$ & 159,26 & 402,29 & D16-500 \\
& Mty & $-610,946$ & - & 402,29 & D16-500 \\
& Mlx & 4363,864 & 1266 & 1609,1 & D16-125 \\
& Mly & 3567,192 & 1161,1 & 1609,1 & D16-125 \\
& Mty & $-589,127$ & 159,26 & 402,29 & D16-500 \\
& Mlx & 3397,49 & 998,6 & 402,29 & D16-500 \\
& Mly & 2806,62 & 889,47 & 1005,7 & D16-125 \\
& Mlx & 523,67 & 140,07 & 402,29 & D16-200 \\
& Mly & 523,67 & 159,59 & 402,29 & D16-500 \\
& Mlx & 507,16 & 135,66 & 402,29 & D16-500 \\
& Mly & 418,96 & - & 402,29 & D16-500 \\
\hline \hline
\end{tabular}

untuk memenuhi persyaratan yang mengacu pada peraturan yang dipakai. Selanjutnya direncanakan layout perairan dermaga LNG yang meliputi Areal Penjangkaran, alur masuk, stopping distance, kolam putar dan kolam dermaga. Tabel 1 menunjukan perbandingan hasil evalusai antara layout rencana awal dan layout perairan yang telah dievalusai, yang menggunakan rumus dari The Overseas Coastal Area Development Institute of Japan [4].

Setalah layout perairan dievaluasi, maka layout daratan dapat direncanakan. Layout daratan yang direncanakan meliputi elevasi dermaga, jarak antara berasting dolphin, jarak antara mooring dolphin, dimens trestle, dimensi pivot, dimensi loading platform, dimensi mooring dolphin, dan dimensi bresating dolphin. Hasil perencanaan dapat dilihat pada Tabel 2 dan Gambar 4.

\section{Perencanaan Struktur Dermaga}

Langkah pertama dalam merencanakan struktur dermaga adalah merencanakan struktur sekunder yaitu pelat lantai. Komponen struktur yang menggunakan struktur pelat adalah unloading platform. Peraturan yang digunakan dalam perencanaan struktur pelat yaitu PBT 1971. Menurut PBI momen tumpuan dan momen lapangan menggunakan persamaan 1 dan Persamaan 2 [5].

$$
\mathrm{M}_{\mathrm{l}} \quad=0,001 \cdot \mathrm{q} \cdot \mathrm{l}_{\mathrm{x}}^{2} \cdot \mathrm{x}
$$


Tabel 5.

Output Gaya-Gaya Dalam UnLoading Paltform

\begin{tabular}{|c|c|c|c|c|}
\hline Struktur & Gaya & Kombinasi & Besar & Satuan \\
\hline & $\mathrm{P}$ (tekan) & COMB 3 & $-0,3$ & $\mathrm{t}$ \\
\hline & $\mathrm{P}($ tarik $)$ & COMB 3 & 0,3 & $\mathrm{t}$ \\
\hline & M3 (tump) & COMB 3 & $-76,38$ & $\mathrm{tm}$ \\
\hline \multirow[t]{7}{*}{ Balok Memanjang 80/80 } & M3 (lap) & COMB 3 & 15,22 & $\mathrm{tm}$ \\
\hline & V2 & COMB 3 & 32,12 & $\mathrm{t}$ \\
\hline & $\mathrm{T}$ & COMB 3 & 1,86 & $\mathrm{tm}$ \\
\hline & Deformasi & ENVELOPE & 1,79 & $\mathrm{~mm}$ \\
\hline & $\mathrm{P}$ (tekan) & COMB 3 & $-0,212$ & $\mathrm{t}$ \\
\hline & $\mathrm{P}($ tarik $)$ & COMB 3 & 0,212 & $\mathrm{t}$ \\
\hline & M3 (tump) & COMB 3 & $-64,51$ & $\mathrm{tm}$ \\
\hline \multirow[t]{7}{*}{ Balok Memanjang 30/50 } & M3 (lap) & COMB 3 & 36,86 & $\mathrm{tm}$ \\
\hline & V2 & COMB 3 & 40,45 & $\mathrm{t}$ \\
\hline & $\mathrm{T}$ & COMB 3 & 4,65 & $\mathrm{tm}$ \\
\hline & Deformasi & ENVELOPE & 1,79 & $\mathrm{~mm}$ \\
\hline & $\mathrm{P}$ (tekan) & COMB 3 & $-0,184$ & $\mathrm{t}$ \\
\hline & $\mathrm{P}$ (tarik) & COMB 3 & 0,184 & $\mathrm{t}$ \\
\hline & M3 (tump) & COMB 4 & $-66,55$ & $\mathrm{tm}$ \\
\hline \multirow[t]{7}{*}{ Balok Melintang 60/90 } & M3 (lap) & COMB 4 & 15,46 & $\mathrm{tm}$ \\
\hline & V2 & COMB 4 & 37,34 & $\mathrm{t}$ \\
\hline & $\mathrm{T}$ & COMB 3 & 3,77 & $\mathrm{tm}$ \\
\hline & Deformasi & ENVELOPE & 5,3 & $\mathrm{~mm}$ \\
\hline & $\mathrm{P}$ (tekan) & COMB 4 & $-148,3$ & $\mathrm{t}$ \\
\hline & $\mathrm{P}($ tarik $)$ & - & - & $\mathrm{t}$ \\
\hline & M2 & COMB 3 & $-45,68$ & $\mathrm{tm}$ \\
\hline \multirow[t]{4}{*}{ Tiang Pancang } & M3 & COMB 4 & 46,38 & $\mathrm{tm}$ \\
\hline & V2 & COMB 3 & 4,2 & $\mathrm{t}$ \\
\hline & V3 & COMB 3 & 4,1 & $\mathrm{t}$ \\
\hline & Deformasi & COMB 3 & 5,3 & $\mathrm{~mm}$ \\
\hline Displacement & $\mathrm{U} 1$ & COMB4 & 5,3 & $\mathrm{~mm}$ \\
\hline
\end{tabular}

Tabel 6.

Penulangan Lentur Tarik Balok

\begin{tabular}{|c|c|c|c|c|c|}
\hline \multirow{2}{*}{ Struktur Trestle } & \multirow{2}{*}{ Posisi } & Momen (M) & \multicolumn{3}{|c|}{$\begin{array}{l}\text { Tulangan Lentur } \\
\text { Tulangan Tarik }\end{array}$} \\
\hline & & (kg.cm) & As Tarik $\left(\mathrm{mm}^{2}\right)$ & As Pakai $\left(\mathrm{mm}^{2}\right)$ & $\begin{array}{c}\text { Jumlah } \\
\text { Tulangan }\end{array}$ \\
\hline \multirow{3}{*}{$\begin{array}{l}\text { Balok Memanjang } \\
60 / 80\end{array}$} & Tumpuan & 6655000 & 4300,1 & 4625,5 & 7D29 \\
\hline & Lapangan & 1546000 & 946,23 & 2643,1 & 4D29 \\
\hline & Tumpuan & 6451000 & 4163,8 & 4625,5 & $7 \mathrm{D} 29$ \\
\hline \multirow[t]{2}{*}{ Balok Melintang 60/80 } & Lapangan & 3686000 & 2328,6 & 2643,1 & $4 \mathrm{D} 29$ \\
\hline & Tumpuan & 7638000 & 4313,1 & 5286,3 & $8 \mathrm{D} 29$ \\
\hline Balok MLA 100/80 & Lapangan & 1522000 & 813,21 & 2643,1 & 4D29 \\
\hline
\end{tabular}

Tabel 7.

Penulangan Lentur Tekan Balok

\begin{tabular}{|c|c|c|c|c|}
\hline \multirow[t]{2}{*}{ Struktur Unloading Platform } & \multirow[t]{2}{*}{ Posisi } & \multicolumn{3}{|c|}{$\begin{array}{l}\text { Tulangan Lentur } \\
\text { Tulangan Tekan }\end{array}$} \\
\hline & & As Tarik $\left(\mathrm{mm}^{2}\right)$ & As Pakai $\left(\mathrm{mm}^{2}\right)$ & Jumlah Tulangan \\
\hline \multirow{4}{*}{ Balok Memanjang 60/80 } & Tumpuan & 1850,2 & 2643,1 & 4D29 \\
\hline & Lapangan & 1057,3 & 1321,6 & 2D29 \\
\hline & Tumpuan & 1850,2 & 2643,1 & 4D29 \\
\hline & Lapangan & 1057,3 & 1321,6 & 2D29 \\
\hline \multicolumn{5}{|l|}{ Balok Melintang 60/80 } \\
\hline \multirow{5}{*}{ Balok MLA 100/80 } & Tumpuan & 2114,5 & 2643,1 & 4D29 \\
\hline & Lapangan & 1057,3 & 1321,6 & 2D29 \\
\hline & & $\mathrm{q}$ & \multicolumn{2}{|c|}{$=$ beban terbagi rata pelat $(\mathrm{t} / \mathrm{m})$} \\
\hline & & $1_{\mathrm{x}}$ & \multicolumn{2}{|c|}{$=$ panjang bentang pendek pelat $(\mathrm{m})$} \\
\hline & & $\mathrm{x}$ & \multicolumn{2}{|c|}{$=$ koefisien dari Tabel 13.3.1 PBI 1971} \\
\hline
\end{tabular}

Berdasarkan persamaan diatas didapat hasil momen maksimum pelat pada unloading platform, dapat dilihat pada Tabel. 3.

Momen maksimum ddigunakan untuk menghitung penulangan pada pelat menggunakan penulangan lentur cara "n" yang disesuaikan kepada PBI 1971 oleh Ir. Wiratman W. Dapat dilihat pada persamaan 3.

Gambar 5. Pemodelan Struktur

\section{Unloading}

Platform

$$
\mathrm{M}_{\mathrm{t}} \quad=-0,001 \cdot \mathrm{q} \cdot \mathrm{1}_{\mathrm{x}}^{2} \cdot \mathrm{x}
$$

Dimana:

$\mathrm{M}_{\mathrm{l}}=$ momen lapangan pelat $(\mathrm{tm})$
$\mathrm{M}_{\mathrm{t}}=$ momen tumpuan pelat $(\mathrm{tm})$

$$
c a=\frac{h}{\sqrt{\frac{n \times M}{b x \sigma^{\prime}}}}
$$

Dimana:

$$
\mathrm{Ca}=\text { Koefisien Penampang }
$$



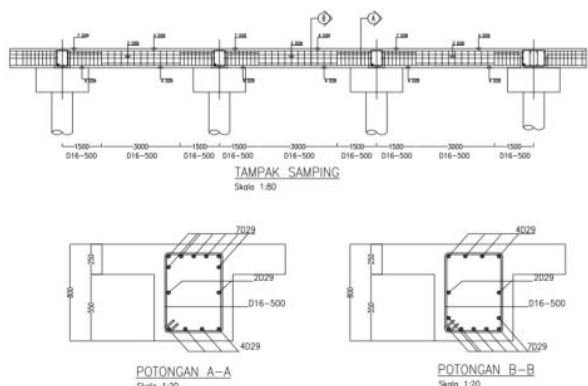

Gambar 6. Detail Penulangan Balok Unloading Platform 1.

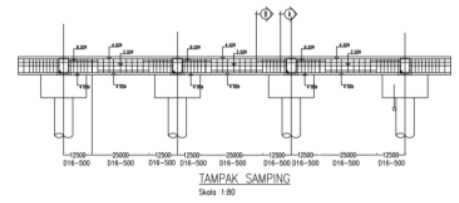

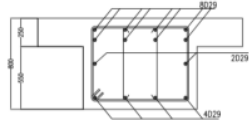

POTONGAN A-A

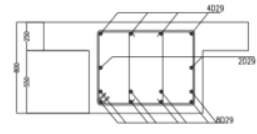

POTONGaN $B-B$
Gambar 7. Detail Penulangan Balok Unloading Platform 2.

$\mathrm{h} \quad=$ Tinggi manfaat penampang

$\mathrm{b} \quad=$ Lebar penampang $($ pelat $=1000 \mathrm{~mm})$

$\mathrm{M}=$ Momen ultimate

$\mathrm{n} \quad=$ Angka ekivalensi baja beton

$\sigma^{\prime}{ }^{\prime}=$ Tegangan ijin baja (tbl 10.4.1 PBI'71)

Setelah didapat nilai $\mathrm{Ca}$, dengan melihat tabel perhitungan lenur cara "n", didapat nilai $\phi$, 100n $\omega$, dan $\omega$. Sehingga dapat dihitung kebutuhan tulangan dengan persamaan 4 . Untuk $\delta=0$.

$\mathrm{A}_{\mathrm{s}} \quad=\omega \times \mathrm{b} \times \mathrm{h}$

Dimana:

$\delta=$ Pebandingan luas luas tulangan tekan A' dengan luas tulangan tarik A

Dari persamaan tersebut didapat kebutuhan tulangan pelat yang dilihat pada Tabel 4.

Tahapan selanjutnya dalam perencanaan struktur adalah perencanaan struktur primer yaitu struktur balok. Perencanaan balok dilakukan dengan melakukan preliminary design dan pemodelan struktur pada SAP2000 pada struktur unloading platform yang dapat dilihat pada Gambar 5 .

Setelah dilakukan pemodelan struktur, didapat output hasil running program SAP 2000 yang dapat dilihat pada Tabel 5, Tabel 6, dan Tabel 7.

Output hasil running SAP2000 digunakan untuk perhitungan struktur utama seperti balok dan tiang pancang. Untuk perhitungan balok, sama seperti peritungan tulangan lentur pada pelat menggunakan lentur cara "n", namun yang membedakan pada balok menggunakan nilai $\delta=0,4$. Rekapitulasi penulangan balok dapat diilihat pada Tabel 6, Tabel 7, dan Tabel 8. Contoh gambar penulangan balok dapat dilihat pada Gambar 6, Gambar 7. Dan Gambar 8.

Dalam merencanakan kedalaman tiang pancang. Dari hasil output SAP2000 didapat nilai $\mathrm{P}_{\mathrm{u}}$ tiang pancang. Hasil tersebut digunakan untuk menentukan kedalaman tiang pancang yang akan di plotkan pada grafik kedalaman vs daya dukung, contoh dilakukan ada struktur unloading platform dengan nilai $\mathrm{Pu}$ tekan sebesar 126,37 ton. Kemudian nilai tersebut di plotkan pada grafik seperti terlihat pada Gambar 8.

Untuk tiang tekan:

$$
\mathrm{Qp}=148,3 \times 2,5=379,11 \text { Ton }(\mathrm{OCDI})
$$

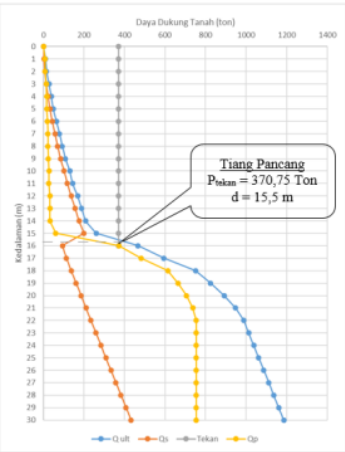

Gambar 8. Kedalaman vs Daya Dukung.

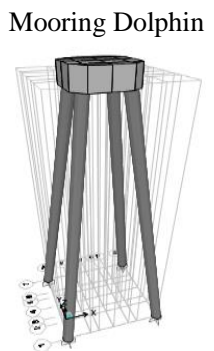

Breasting Dolphin

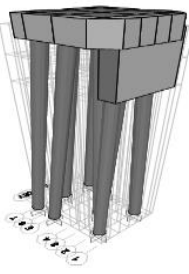

Gambar 8. Pemodelan Struktur.

Dengan gaya tekan tersebut maka dibutuhkan kedalaman tiang minimum sedalam $-15,5 \mathrm{~m}$ di bawah seabed atau -25,5 mLWS. Kemudian dilakukan pengecekan kontrol kekuatan yang terjadi pada tiangpancang tersebut. Beban yang dipikul oleh tiap pancang tidak hanya beban vertikal tetapi pada beban horizontal Gaya horizontal yang terjadi (hasil perhitungan pada SAP2000) harus lebih kecil dari gaya horizontal yang mampu dipikul beban (Hu). [6]

Setelah dilakukan perencanaan unloading platform, selanjutnya direncanakan struktur mooring dolphin dan breasting dolphin. Perencanaan secara prinsip sama seperti pada elemen struktur sebelumnya, namun untuk mooring dolphin dan breasting dolphin hanya terdiri dari poer dan tiang pancang. Untuk menghitung kebutuhan penulangan dilakukan pemodelan struktur yang dapat dilihat pada Gambar 10. Output hasil running program SAP200 dapat dilihat pada Tabel 9 dan Tabel 10.

Dari output Tabel 9 dan 10 dapat dihitung kebutuhan tulangan poer yang dapat dilihat pada Tabel 11 dan Gambar 9 dan Gambar 10. Nilai P Tekan dan P tarik pada Tabel 11 dan Tabel 12 digunakan untuk menentukan kedalaman tiang pancang.

Hasil analisa gaya dalam yang terjadi pada tiang pancang dapat dilihat pada Gambar 11.

$\mathrm{Qp} \quad=$ SF $\times$ P tarik (OCDI)

$$
=2,5 \times 25,9 \text { Ton }
$$$$
=64,75 \text { Ton }
$$

Dengan gaya tekan tersebut maka dibutuhkan kedalaman tiang minimum sedalam $24 \mathrm{~m}$ dibawah seabed atau $-33 \mathrm{~m} \mathrm{LWs}$

Qp $\quad=$ SF $x$ P tekan (OCDI)

$$
\begin{aligned}
& =2,5 \times 75,94 \text { Ton } \\
& =227,82 \text { Ton }
\end{aligned}
$$

Dengan gaya tekan tersebut maka dibutuhkan kedalaman tiang minimum sedalam $13 \mathrm{~m}$ dibawah seabed atau $-23 \mathrm{~m}$ LWS. Sehingga kedalaman mooring dolphin dapat ditentukan yaitu $-23 \mathrm{~m} \mathrm{LWS}$.

Perencanaan struktur selanjutnya adalah struktur catwalk yang berfungsi sebagai struktur penghubung antar elemen struktur. Dilakukan dengan memodelkan pada SAP2000 
Tabel 9.

Ouput Gaya-Gaya Dalam Mooring Dolphin

\begin{tabular}{ccccc}
\hline \hline Struktur & Gaya & Kombinasi & Besar & Satuan \\
\hline \multirow{2}{*}{ Poer } & M11 & COMB3 & 45,16 & tm \\
& M22 & COMB3 & 41,49 & tm \\
& P (tekan) & COMB3 & $-75,94$ & $\mathrm{t}$ \\
Tiang & P (tarik) & COMB3 & 25,9 & $\mathrm{t}$ \\
Pancang & M2 & COMB4 & $-41,02$ & $\mathrm{tm}$ \\
& M3 & COMB3 & $-43,46$ & $\mathrm{tm}$ \\
& V2 & COMB3 & 3,84 & $\mathrm{t}$ \\
Defleksi & V3 & COMB3 & 3,24 & $\mathrm{t}$ \\
\hline \hline
\end{tabular}

Tabel 10.

Ouput Gaya-Gaya Dalam Breasting Dolphin

\begin{tabular}{ccccc}
\hline \hline Struktur & Gaya & Kombinasi & Besar & Satuan \\
\hline \multirow{2}{*}{ Poer } & M11 & COMB3 & 82,56 & $\mathrm{tm}$ \\
& M22 & COMB3 & 80,22 & $\mathrm{tm}$ \\
& $\mathrm{P}$ (tekan) & COMB3 & $-128,032$ & $\mathrm{t}$ \\
& $\mathrm{P}$ (tarik) & COMB3 & 77,58 & $\mathrm{t}$ \\
Tiang & M2 & COMB3 & 96,14 & $\mathrm{tm}$ \\
Pancang & M3 & COMB3 & 95,6 & $\mathrm{tm}$ \\
& V2 & COMB3 & 8,41 & $\mathrm{t}$ \\
& V3 & COMB3 & 8,13 & $\mathrm{t}$ \\
Defleksi & $\mathrm{U} 1$ & COMB2 & 1,2 & $\mathrm{~mm}$ \\
\hline \hline
\end{tabular}

Tabel 11.

Penulangan Poer Mooring Dolphin dan Breasting Dolphin

\begin{tabular}{|c|c|c|c|c|}
\hline $\begin{array}{l}\text { Elemen } \\
\text { Struktur }\end{array}$ & Tipe & Nilai Ca & $\begin{array}{c}\text { Letak } \\
\text { Tulangan }\end{array}$ & $\begin{array}{c}\text { Tulangan } \\
\text { Pasang }\end{array}$ \\
\hline Mooring & Poer Arah x & 4,831 & $\begin{array}{c}\text { Tarik } \\
\text { Samping }\end{array}$ & $\begin{array}{c}\mathrm{D} 29-200 \\
5 \mathrm{D} 29\end{array}$ \\
\hline Dolphin & Poer Arah y & 4,676 & $\begin{array}{c}\text { Tarik } \\
\text { Samping }\end{array}$ & $\begin{array}{c}\text { D29-200 } \\
5 \mathrm{D} 29\end{array}$ \\
\hline Breasting & Poer Arah x & 5,546 & $\begin{array}{c}\text { Tarik } \\
\text { Samping }\end{array}$ & $\begin{array}{c}\mathrm{D} 29-125 \\
5 \mathrm{D} 29\end{array}$ \\
\hline Dolphin & Poer Arah y & 5,432 & $\begin{array}{c}\text { Tarik } \\
\text { Samping } \\
\end{array}$ & $\begin{array}{c}\mathrm{D} 29-125 \\
5 \mathrm{D} 29 \\
\end{array}$ \\
\hline
\end{tabular}

Tabel 12

Ouput Gaya-Gaya Balok Utama

\begin{tabular}{ccccc}
\multicolumn{5}{c}{ Ouput Gaya-Gaya Balok Utama } \\
\hline \hline Frame & Beban & Kombinasi & Besar & Sat \\
\hline 56 & P ( Tarik ) & $1,2 \mathrm{DL}+1,6 \mathrm{LL}$ & 67,11 & $\mathrm{t}$ \\
23 & P ( Tekan ) & $1,2 \mathrm{DL}+1,6 \mathrm{LL}$ & 3,05 & $\mathrm{t}$ \\
29 & $\mathrm{~V}$ & $1,2 \mathrm{DL}+1,6 \mathrm{LL}$ & 0,412 & $\mathrm{t}$ \\
26 & $\mathrm{M}$ & $1,2 \mathrm{DL}+1,6 \mathrm{LL}$ & 0,34 & $\mathrm{t} . \mathrm{m}$ \\
54 & $\mathrm{u}$ & $1,2 \mathrm{DL}+1,6 \mathrm{LL}$ & 2,91 & $\mathrm{~mm}$ \\
\hline \hline
\end{tabular}

Tabel 13.

Output Gaya-Gaya Balok Rangka

\begin{tabular}{cccccc}
\hline \hline Frame & & Beban & Kombinasi & Besar & Sat \\
\cline { 1 - 3 } \cline { 5 - 6 } \cline { 5 - 6 } & P ( Tarik ) & $1,2 \mathrm{DL}+1,6 \mathrm{LL}$ & 8,56 & $\mathrm{t}$ \\
55 & $\mathrm{P}$ ( Tekan ) & $1,2 \mathrm{DL}+1,6 \mathrm{LL}$ & 8,33 & $\mathrm{t}$ \\
65 & $\mathrm{~V}$ & $1,2 \mathrm{DL}+1,6 \mathrm{LL}$ & 0,21 & $\mathrm{t}$ \\
65 & $\mathrm{M}$ & $1,2 \mathrm{DL}+1,6 \mathrm{LL}$ & 0,062 & $\mathrm{t} . \mathrm{m}$ \\
64 & $\mathrm{u}$ & $1,2 \mathrm{DL}+1,6 \mathrm{LL}$ & 2,91 & $\mathrm{~mm}$ \\
\hline \hline
\end{tabular}

dengan dimensi balok utama CHS 219,1 mm dan dimensi balok rangka $114,3 \mathrm{~mm}$ dan output hasil runningnya digunakan untuk kontrol kekuatan dari struktur catwalk. Pemodelan Struktur dan output SAP2000 dapat dilihat pada Gambar 12, Tabel 12, dan Tabel 13.

\section{Metode Pelaksanaan}

Dalam bab metode pelaksanaan ini, akan direncanakan metode pelaksanaan dari hasil perencanaan pada bab-bab sebelumnya yang meliputi:

1. Metode pelaksanaan Dermaga (Unloading Platform, Mooring Dolphin, Breasting Dolphin).

2. Metode pelaksanaan Catwalk.

Dalam pelaksanaan struktur dermaga pupuk NPK, perencanaan dibagi menjadi 3 tahap:

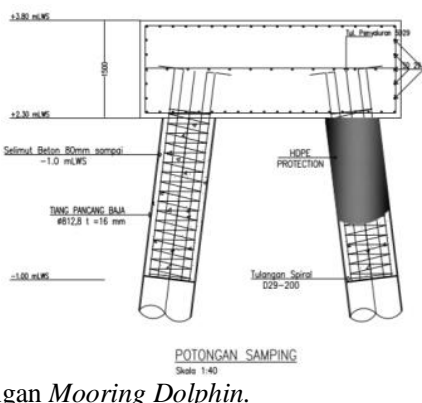

Gambar 9. Penulangan Mooring Dolphin.
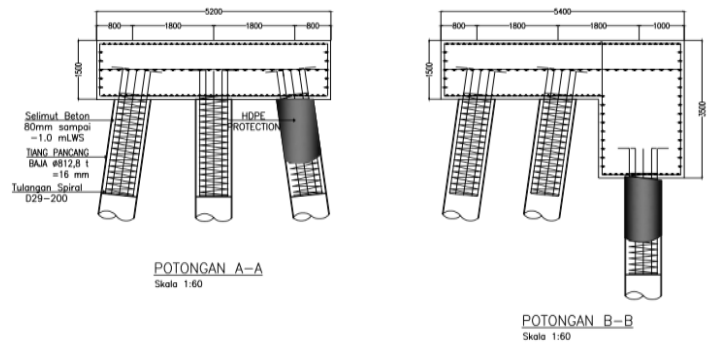

Gambar 10. Penulangan Breasting Dolphin.

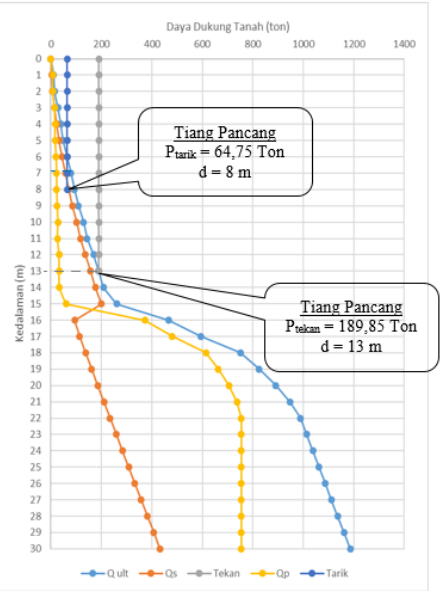

Gambar 11. Kedalaman vs Daya Dukung.

1. Tahap prakonstruksi

2. Tahap konstruksi

3. Tahap pasca konstruksi

Pekerjaan tahap konstruksi dapat dibagi menurut urutan pengerjaannya. Adapun tahap-tahap konstruksi adalah sebagai berikut:

1. Pemancangan tiang pancang baja.

2. Pemasangan selimut beton dan beton isi tiang.

3. Metode pelaksanaan poer.

4. Metode pelaksanaan balok dan pelat.

5. Merode Pemasangan fender dan bollard.

\section{E. Rencana Anggaran Biaya}

Pekerjaan yang dihitung untuk perencanan anggaran biaya meliputi pekerjaan persiapan, pekerjaan mooring dolphin, pekerjaan breasting dolphin, pekerjaan unloading platform, pekerjaan catwalk.

Adapun hasil rekapitulasi perhitungan Rencana Anggaran Biaya dapat dilihat pada Tabel 14.

\section{KESIMPULAN}

Berdasarkan keseluruhan hasil perencanaan diperoleh kesimpulan sebagai berikut:

1. Spesifikasi kapal rencana: 


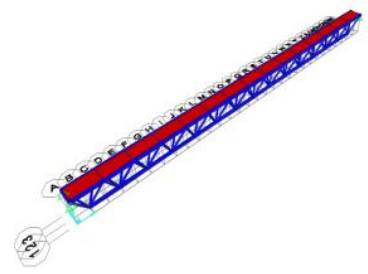

Gambar 12. Pemodelan Struktur Catwalk.

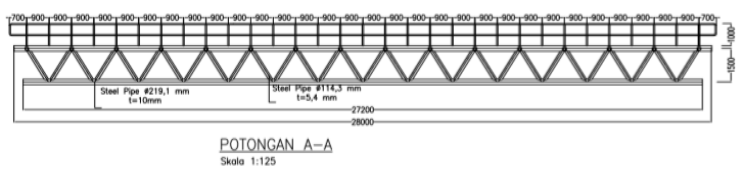

Gambar 13. Detail Struktur Catwalk.

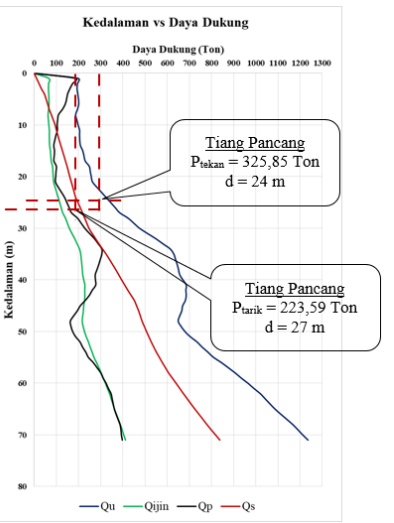

Gambar 14. Kedalaman vs Daya Dukung.

$\begin{array}{ll}\text { DWT } & : 10.000 \text { ton } \\ \text { Panjang kapal (LOA) } & : 143,5 \mathrm{~m} \\ \text { Lebar kapal (B) } & : 23,1 \mathrm{~m} \\ \text { D (Depth) } & : 11,5 \mathrm{~m} \\ \text { Draft kapal } & : 8 \mathrm{~m}\end{array}$

2. Struktur dermaga yang direncanakan terdiri dari Unloading Platform, Breasting Dolphin, Mooring Dolphin dan Catwalk.

3. Struktur Unloading Platform direncanakan beton bertulang dengan spesifikasi:

$\begin{array}{ll}\text { Dimensi struktur } & : 22 \times 19 \mathrm{~m} \\ \text { Dimensi balok melintang } & : 60 \times 80 \mathrm{~cm} \\ \text { Dimensi balok memanjang } & : 60 \times 80 \mathrm{~cm} \\ \text { Dimensi balok MLA } & : 100 \times 80 \mathrm{~cm} \\ \text { Tebal Pelat } & : 25 \mathrm{~cm} \\ \text { Mutu beton } & : \mathrm{K}-350 \\ \text { Mutu baja } & : \text { BjTS } 40 \\ \text { Poer pancang ganda } & : 200 \times 200 \times 100\end{array}$

Tiang pancang : $\varnothing 812,8 \mathrm{~mm}$

4. Struktur Breasting Dolphin direncanakan beton bertulang dengan spesifikasi:

Dimensi struktur

Tebal poer

$: 5,4 \times 5,2 \mathrm{~m}$

Mutu beton

$: 150 \mathrm{~cm}$

: $\mathrm{K}-350$

Mutu baja

: BjTS 40

Fender

: SCN 1800 F0.7

Tiang pancang

Kemiringan tiang

: $\varnothing 812,8 \mathrm{~mm}$

$: 8: 1$

5. Struktur Mooring Dolphin direncanakan beton bertulang dengan spesifikasi:

Dimensi struktur

: 4 x $4 \mathrm{~m}$
Tabel 14

Rekapitulasi RAB

\begin{tabular}{clc}
\hline \multicolumn{2}{c}{ Rekapitulas Biaya } \\
\hline NO. & \multicolumn{1}{c}{ Uraian Pekerjaan } & Harga Pekerjaan \\
I & Pekerjaan Persiapan & Rp1.850.534.000 \\
II & Pekerjaan Mooring Dolphin & Rp11.326.054.861 \\
III & Pekerjaan Breasting Dolphin & Rp11.043.674.768 \\
IV & Pekerjaan Unloading Platform & Rp17.198.076.680 \\
V & Pekerjaan Dudukan Catwalk & Rp1.630.333.431 \\
VI & Pekerjaan Catwalk & Rp2.263.547.500 \\
& Total & Rp45.312.221.240 \\
& PPn 10\% & Rp4.531.222.124 \\
& Jumlah Akhir & Rp49.843.443.364 \\
& Jumlah Akhir (dibulatkan) & Rp49.843.444.000
\end{tabular}

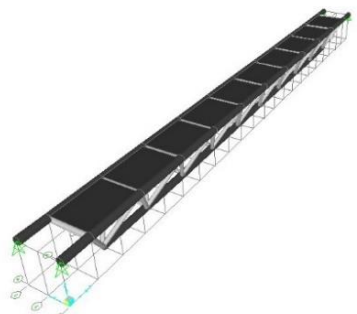

Gambar 15. Pemodelan Struktur Catwalk..
Tebal poer

Mutu beton

Mutu baja

Boulder

Tiang pancang

Kemiringan tiang
$: 100 \mathrm{~cm}$

: K - 350

: BjTS 40

: QRH

$: 8: 1$
6. Struktur Catwalk direncanakan sebagai struktur rangka Circular Hollow Section dengan spesifikasi:

Bentang Struktur : $7 ; 16 ; 28 \mathrm{~m}$

Dimensi Balok memanjang : CHS $200 \mathrm{~mm}$

Dimensi Balok melintang : CHS $100 \mathrm{~mm}$

Lebar Pelat Injakan $\quad: 1,5 \mathrm{~m}$

Pelat Injak : I Bar Grating

Jarak antar balok melintang $: 1,8 \mathrm{~m}$

Dimensi Poer Bangunan Bawah : : 3,2 x 1,6 x 0,6

7. Rencana anggaran biaya yang diperlukan untuk pembangunan dermaga LNG di Maros Sulawesi Selatan untuk kapal LNG kapasitas 10.000 DWT sebesar: Rp49.843.444.000,- (Empat Puluh Sembilan Milyar Delapan Ratus Empat Puluh Tiga Juta Empat Ratus Empat Puluh Empat Ribu Rupiah). Gambar 13. Detail Struktur Catwalk.Gambar 14. Kedalaman vs Daya Dukung. Gambar 15. Pemodelan Struktur Catwalk.

\section{DAFTAR PUSTAKA}

[1] H. Velsink, Ports and Terminals Planning and Functional Design. Netherlands: TU Delft, 1994

[2] C. A. Thoresen, Port Designer's Handbook. British: Thomas Telford, 2003.

[3] Badan Standardisasi Nasional, "SNI-03-1726-2012-Standar Perencanaan Ketahanan Gempa Untuk Struktur Bangunan Gedung." BSNi, Bandung, 2012.

[4] OCDI, Technical Standards and Commentaries for Port and Harbour Facilities in Japan. Japan. Japan: Daikousha Printing Co.,Ltd., 2002.

[5] Lembaga Penyelidikan Masalah Bangunan, Peraturan Beton Bertulang Indonesia. 1971.

[6] H. Wahyudi, Daya Dukung Pondasi Dalam. Surabaya: ITS Press, 2013. 